\title{
The Global Democrat
}

The new era of human relationships in which we live is one marked by mass production for remote markets, by cable and telephone, by cheap printing, by railway and steam navigation. Only geographically did Columbus discover a new world. The actual new world has been generated in the last hundred years. (LW2: 323)

As the last chapter made clear, John Dewey's conception of creative democracy points towards the perpetual adaption of social institutions, including democratic institutions and practices themselves, as new publics are engendered by social change. In this chapter, I aim to highlight how Dewey's conception of creative democracy was also informed by what he took to be the global interdependence of the Great Society. This centres on how Dewey believed that creative democracy needed to be exercised not only within America, but also outside and between nation states and the various publics engendered and scattered across the globe by what we have come to call the First Great Globalization. To achieve this, the chapter will consist of three sections. The first section highlights the globalized nature of the Great Society by showing how such a time period has today become known as the 'First Great Globalization'. The second section focuses not only on how Dewey acknowledged the global dimensions of the Great Society but also on why he was compelled to propound the need for global democracy. The final part of the chapter outlines Dewey's concrete ideas about what global democracy would look like in reality. 


\section{The Great Society as the First Great Globalization}

Pragmatist scholars often fail to recognize that Dewey saw the Great Society as more than the radical transformation of the American nation state from an agrarian to a corporate capitalist society. ${ }^{1} \mathrm{He}$ also saw it as the concomitant radical transformation of the global economy that took place during what has become known as 'the long nineteenth century' (1815-1914). What exactly, then, was this great transformation? Prior to the nineteenth century, there existed a well-defined intercontinental trade system that linked Europe, Asia and the Atlantic colonies of European empires (Findlay and O'Rourke 2007: 365). This had seen world trade grow at 1 per cent per year during the seventeenth and eighteenth centuries. However, as writers such as Frieden (2006), Findlay and O'Rourke (2007) and Rodrik (2011) point out, the long nineteenth century saw the radical transformation of global trade and finance. The transformation of the global economy that took place during the long nineteenth century is now taken to be 'The First Great Globalization.'

The First Great Globalization was driven by historical factors such as the industrial revolution and its new forms of travel (steamships, railways) and communications technology (wireless telegraphs and telephones) that reduced inefficiency and the transaction costs of world trade. Factors such as the hegemonic ascent of free trade ideas as espoused by Smith and Ricardo; the subjection of national macroeconomics to the priorities of the international monetary system of the gold standard; the economic hegemon's (Britain) embrace and upholding of the gold standard; free trade and the consequent export of investment capital by the City of London; the global migration from the Old World to the New World; and European imperialism and the opening up of Asia to free trade combined to create the first genuine integrated world economy. The First Great Globalization thus translated into a scenario in which:

... the world economy was essentially open to the movement of people, money, capital and goods. The leading businessmen, politicians, and thinkers of the day regarded an open world economy as the 
normal state of affairs. They assumed that people and money would flow around the world with few or no restrictions. Trade protection, although common, was seen as an acceptable departure from the norm, driven by the exigencies of short-term domestic or international politics. Capitalism was global, and the globe was capitalist. (Frieden 2006: 29)

By the mid-nineteenth century, the onset of the First Great Globalization saw world trade grow at a rate of 4 per cent per year for the rest of the century (Rodrik 2011:24-5). By 1913, every country in Western Europe, bar Spain and Portugal, had industrialized and such developments also took place in countries such as Argentina and Japan. Moreover, a global economic regime emerged across what we today call asymmetric global North and South relations. In this global division of labour, the rich and industrial North, normally under a regime of formal or informal imperialism, exported industrial products in exchange for the primary commodity exports of the poor and largely agricultural South (Findlay and O'Rourke 2007: 402-7, 412-15). Writing in 1919, and over what he perceived as the burning embers of such an order, John Maynard Keynes provides a wonderfully colourful first-hand account of what is meant by the First Great Globalization:

What an extraordinary episode in the economic progress of man that age was which came to an end in August $1914 \ldots$ The inhabitant of London could order by telephone, sipping his morning tea in bed, the various products of the whole earth, in such quantity as he might see fit, and reasonably expect their early delivery upon his doorstep; he could at the same moment and by the same means adventure his wealth in the natural resources and new enterprises of any quarter of the world, and share, without exertion or even trouble, in their prospective fruits and advantages; or he could decide to couple the security of his fortunes with the good faith of the townspeople of any substantial municipality in any continent that fancy or information might recommend... But, most important of all, he regarded this state of affairs as normal, certain, and permanent, except in the direction of further improvement, and any deviation from it as aberrant, scandalous, and avoidable. The projects and politics of militarism 
and imperialism, of racial and cultural rivalries, of monopolies, restrictions, and exclusion, which were to play the serpent to this paradise, were little more than the amusements of his daily newspaper, and appeared to exercise almost no influence at all on the ordinary course of social and economic life, the internationalization of which was nearly complete in practice. (Keynes 1919: 6-7)

As Keynes alludes to above, the long nineteenth century and its globalization was eventually brought to a shuddering halt by the outbreak of the First World War and the rise of trade protectionism that arose from such a global conflict. The period after the war is commonly held to be a period of 'de-globalization' with the onset of 1920s hyperinflation, the Great Depression, trade protectionism and xenophobic nationalism, seeing the world economy split into autarkic economic blocs (Findlay and O'Rourke 2007). ${ }^{3}$ However, the evocation of the term 'de-globalization' is slightly misleading as it misses the foolish attempt, between 1925 and 1929, of the developed powers such as Great Britain and the United States to restore the world economy through the re-establishment of the gold standard. ${ }^{4}$ As such, even after the war, and in the midst of some trade protectionism and the project of rebuilding Europe, the world's industrial production grew by more than a fifth between 1925 and 1929. And with the rise of Americanstyle mass production and mass consumption, exports swelled to double pre-war levels and world trade became 42 per cent greater in 1929 than in 1913.

This boom was primarily created by the rise of American economic hegemony and Wall Street's usurpation of the City of London as the world's financial centre. Although the United States rejected Britain's political engagement and formal imperialistic underpinning of the long nineteenth century, the rise of American investment capital, taking over from the role of European investment capital, saw over $£ 1$ billion a year in loans emanating from New York to foreign destinations between 1919 and 1929. Between 1924 and 1928, America lent on average $\$ 500$ million per year to Europe, $\$ 300$ million per year to Latin America, \$200 million per year to Canada and \$100 million 
per year to Asia. In tandem, American industrialists and corporations also scoured the globe for foreign direct investment in plants and other ventures. Over the 1920s, American firms invested some $\$ 5$ billion overseas and saw the rise of multinational corporations such as Ford and General Motors (GM), who became well established in major and minor economies across the globe, and the internationalization of the activities of American commercial banks (Frieden 2006: 140-1, 160-1).

Despite this global economic integration, the reality was that the United States during this period embraced forms of political isolationism in comparison to the international political 'conductor' Great Britain had been when she was the world's pre-eminent economic power. This, of course, was all to lead into the void of the Great Depression and the spread of autarky and ultranationalism. However, the key point is that the ideals of the long nineteenth century and the First Great Globalization still cast a large shadow over the activities of not only America but also the globe post-1914. The question this book seeks to answer is how the casting of such a shadow appeared to John Dewey. As I discuss later, Dewey fully understood that the Great Society was inherently both a national and an international creature.

\section{Dewey's plea for a global Great Community}

By 1927, when Dewey wrote The Public and Its Problems, he was aware that the First Great Globalization was heavily linked to the problems of publics and the practice of creative democracy within what he called the Great Society. The conception of the Great Society in The Public and Its Problems encompasses not only the great transformation of American life but also the global interdependence created by the First Great Globalization. Unfortunately, Deweyan scholars rarely take the global dimensions of the Great Society seriously enough. ${ }^{5}$ As a result, what is often missed is how the global dimensions of the Great Society fundamentally informed Dewey's conception of the praxis of creative democracy. Moreover, if read with this understanding 
in mind, Dewey's political writings from the 1920s onwards can be seen as untangling two intertwined threads concerning the pursuit of democracy as a way of life and the practice of creative democracy within the Great Society.

The first thread, which has been covered by some authors such as Westbrook (1991) and Kadlec (2007), but which has been largely marginalized in other appraisals of Dewey's work, concerns the effects of the Great Society, the rise of democratic realism and the need for democracy as a way of life within America. Nevertheless, Dewey was also aware that much of the complexity and stratification he associated with American corporate capitalism and what he took as the Great Society were engendered by developments of the global economy and the relations between nation states. The second thread, which is even more marginalized than the first in accounts of Dewey's work, recognizes the Great Society not only as an American phenomena but as a state of affairs engendered by what we today call the First Great Globalization and establishes the need for creative democracy at the international level:

It can be confidently affirmed that every aspect, content, structure and phase of human life has been radically changed, directly or indirectly, for weal or woe, by proliferating and accelerating industrialtechnological revolutions. For example: they have changed the structure of family life, the status of women, the relations of the sexes, of parents and children; education has been changed in every respect, quantitatively and qualitatively; vast populations have been urbanized, imposing new occupations and new ways of life; transportation and communication have been revolutionized, with incalculable human consequences; intra-national and international relations, friendly and hostile, cooperative and competitive have been multiplied and intensified; local and world-wide class and race problems have been generated or exacerbated. (LW1: 358)

In The Public and Its Problems, Dewey summed this state of affairs up as a 'new era of human relationships' (LW2: 323). ${ }^{6}$ Not only did Dewey recognize such unprecedented economic interdependence in 
and between nation states as the greatest change in human history, but also that such change now created forms of associated behaviour and consequences of associated behaviour that spanned national and continental boundaries. Hence, Dewey believed that the irony of the nineteenth and early twentieth century was that the '... consolation of peoples in enclosed, nominally independent, national states has its counterpart in the fact that their acts affect groups and individuals in other states all over the world' (LW2: 315, cf. LW13: 190).

In The Public and Its Problems, the most striking exemplar of the global nature of the Great Society provided by Dewey is the First World War and its aftermath. Dewey begins by highlighting how the war itself was truly global with the involvement of 'every continent upon the globe. Colonial possessions were drawn in, self-governing nations entered voluntarily and countries with racial and cultural differences, such as Great Britain and Japan and Germany and Turkey, formed alliances. However, the global nature of the conflict aside, Dewey took the First World War to reveal the interdependence of countries in the Great Society and that the consequences of associated behaviour often did not respect national borders. For instance, Dewey highlights how the breakdown of world trade during the war saw a consequent scramble by the belligerents to secure commodities such as raw materials, distant economic markets and foreign capital, which had previously been in abundance due to economic interdependence prior to the war (LW2: 314-17).

At the same time, Dewey saw that the breakdown of such global economic relations created consequences for the everyday life of people across the globe. For example, American farmers, who had experienced temporary prosperity through the increase in demand for agricultural products during the war, saw their economic outlook become bleak when the consequences of the establishment of peace (war debts, the centralization of gold reserves in the United States, depreciations of foreign currencies) meant that wartime levels of export demand declined and failed to return to pre-war levels. Dewey fully acknowledged that the misfortune of American farmers was relatively 
insignificant in comparison with the other consequences of peace, such as the hyperinflation in Germany and the stimulation of European nationalisms, but it revealed how day-to-day life in one region of the world was now fundamentally linked to, and affected by, the behaviour of others on the far side of the world (LW2: 316).

In essence, the First World War vividly brought home for Dewey how the interdependence of nation states in the Great Society meant the consequences of associative behaviour now spanned across borders. Rather than being a matter of sheer empirical description, however, Dewey found that the case of the American farmer illustrated how little 'prevision and regulation' of such transcontinental interdependence actually existed and how people had as much control over such events as they had over the vicissitudes of the climate (LW2: 316). In 1927, then, the political conclusion he drew from the global nature of the Great Society and the World War it had helped to facilitate was how the existing political and legal institutions and practices were incapable of dealing with the current situation. Contrasting his present with that of Pax Romana, Dewey contended that:

There was a critical epoch in the history of the world when the Roman Empire assembled in itself the lands and peoples of the Mediterranean basin. The World War stands out as an indubitable proof that what then happened for a region has now happened for the world, only there is now no comprehensive political organization to include the various divided yet interdependent countries. Any one who even partially visualizes the scene has a convincing reminder of the meaning of the Great Society: that it exists, and that it is not integrated. (LW2: 315)

Dewey was all too aware that the reality of globalization now required reform of government that would allow for transnational communication and collaboration and global forms of democratic government. The Great Society needed to become a Great Community which could perfect '.. the means and ways of communication of meanings so that genuinely shared interests in the consequences of interdependent activities may inform desire and effort and thereby direct action' (LW2 332, cf. 314, 327). 
One can find the same sustained, if not ever-growing, conviction that the Great Society was engendered by modern globalization and lacked political regulation at the international level when one reads elements of Dewey's work through the Great Depression and the rise of trade protectionism, the build-up to the Second World War and in the aftermath of the defeat of the Axis Powers. ${ }^{7}$ The intervening years made it clear for Dewey that without a common rule of law and a machinery of government at the international level to manage the effects of the Great Society, the only way nation states knew or sought to deal with the effects of such globalization was economic (autarky, trade protectionism) or military form of warfare (LW11: 261-2).

The fait accompli that was the Second World War highlighted for Dewey the '.. futility of all thinking, planning and practical effort that is not global in reach' (LW17: 545). Writing in 1944, Dewey outlined again that the Great Society was engendered by the First Great Globalization and had created an interdependent world:

Commerce, industry, growth of the means of communication between countries physically far apart, did in fact produce interdependence. As Mr. Willkie recently reminded us, we now live in what to all intents and purposes is One World. Distance, the isolating and divisive power of the seas and vast spaces, has been overcome. Steamship and ocean cables began a work which radio and airplane have carried through. For good or bad, we are now and henceforth more like close neighbors in a crowded city than like the widely separate peoples in which our grandparents carried on their affairs in government and industry. $(\text { LW17: 453) })^{8}$

Dewey now identified the biggest problem facing the emergence of the Great Community to be the fact that our political beliefs and standards had fallen out of synch with reality. The First Great Globalization had not only brought about physical interdependence across the globe but also engendered a raft of ideas about the teleological advance of democracy, peace and prosperity across the globe. The mistake, Dewey argued, was not the embrace of physical interdependence but the mistaken belief that the breaking down of '.. physical barriers, 
the mere bringing of peoples together into physical contact, would automatically create moral unification' (LW17: 453-4). Humanity was now literally stuck in between 'two worlds' where its political ideas did not match its physical realities:

One does not have to argue to prove the existence of global physical conditions. It is enough to point to the war in which this country along with almost every country of the globe is engaged. But the fact that it is war which provides the evidence is also proof of absence of moral unification. It points to the nature of the scope, the immensity and the intensity, of the task which lies ahead of us. It points to the futility of all thinking, planning and practical effort that is not global in reach. As yet these things are still largely local, provincial. Politically, our beliefs and standards are nationalistic, not global. (LW17: 454-5)

After the Second World War, Dewey strengthened this line of argument by adding that the war highlighted that the old traditions, customs, habits of belief and institutions of 'old-time diplomacy, power blocs, power politics and precepts of international law' were now as 'outworn and impotent as the old-time muzzle-loading gun' in dealing with the transnational reality of the Great Society. Dewey argued that a world with such interdependence, lacking the means to deal with the effects of such interdependence short of forms of warfare, was essentially a form of 'anarchy'. It was now the 'tragedy of our time' that every person on the planet belonged to a 'world unit' which did not possess a common rule of law and a machinery of government at the international level to manage the international effects of the Great Society (LW15: 204). As such, Dewey declared that:

...the responsibility now placed upon us is that of creating the intellectual and moral attitudes that will support institutions, international and domestic, political, educational and cultural, that correspond to the physical revolution which has taken place; and whose consequences are so largely negative just because of the absence of corresponding institutional change. (LW17: 456) ${ }^{9}$

This fact became all the more poignant in the light of the unprecedented destructiveness of the Second World War and the rise of atomic age, 
which now handed humanity the ability to seemingly wipe itself out of existence (LW1: 358; LW15: 199-202)

\section{Global creative democracy}

What, then, of Dewey's concrete ideas about how global democracy could provide governance of the Great Society and how did he think it could be brought into being? Dewey never explained his plans for what such global democracy would look like in a systematic way. Indeed, given his conception of publics amending social institutions in reaction to change and its consequences, such overarching blueprints of global democracy would be somewhat antithetical to Dewey's own idea of creative democracy. However, Dewey as a citizen and public intellectual was also part of publics throughout his life, and his own views of what creative democracy at the global level would look can be teased out from his writings on international affairs. These references to global democracy were not just taken by Dewey as being mere flights of political fancy but based on concrete possibilities in the present.

Dewey's approach to global democracy is essentially two-pronged: it deals with relations between nation states and publics in, and between, those national populations. In the first instance, Dewey's writings in the aftermath of the destruction left by the First World War highlight his belief that the old order of international liberal capitalism, underwritten by imperialism and asymmetric global North/South relations, could be replaced if humanity realized that it was democracy 'for which we are fighting' (MW11: 98-106). Writing in 1918, Dewey argued that peace now brought new problems for social regulation between nation states such as the distribution of labour, immigration and production for export. To subsequently '.. annihilate or reduce the agencies of international regulation which already exist ..., instead of stabilizing and expanding their scope, Dewey argued, would therefore be 'almost incredible stupidity' (MW11: 130). The world now faced the choice 
between a return to the status quo of imperialistic rivalry and a new form of global democracy through new institutions of global governance:

While one can say here as in the case of international relations that a more highly organized world is bound to result, one cannot with assurance say which of the two types of organization is going to prevail. But it is reasonably sure that the solution in one sphere will be congruous with that wrought out in the other. Governmental capitalism will stimulate and be stimulated by the formation of a few large imperialistic organizations which must resort to armament for each to maintain its place within a precarious balance of powers. A federated concert of nations, on the other hand, with appropriate agencies of legislation, judicial procedure and administrative commissions would so relax tension between states as to encourage voluntary groupings all over the world, and thus promote social integration by means of the cooperation of democratically self-governed industrial and vocational groups. (MW11: 105)

Dewey furthered this idea of a new form of global democratic government when he turned his attention to the newly founded League of Nations. In 1918, Dewey saw the League of Nations as a chance to 'end international anarchy' through an embracement of a new form of 'diplomacy', which would displace the elite and aristocratic style of 'old diplomacy' (M11: 132). Despite his eventual disillusionment with post-war international politics, Dewey believed that global democracy required forms of global or international institutions (legislative, judicial, economic) that could regulate the Great Society. These institutions would be pivotal to balance the inequality of power smaller and weaker nations faced from economically and militarily powerful nations and empires (MW11: 139-42). ${ }^{10}$

Dewey did, however, augment his embrace of new international institutions with the notion that to have a 'safe world for democracy' and a world in which democracy was 'anchored' required not only a worldfederated government but also the emergence of a 'variety of freely experimenting and freely cooperating self-governing local, cultural and industrial groups' (MW11: 105). This can be seen as Dewey offering a 
forerunner for ideas of global civil society or the global public sphere. However, by the 1920s, Dewey pushed this argument about the role of public even further. The reformation of the international order towards global democracy was now only possible through both the emergence of a new global architecture of institutions and the 'non-political forces organising themselves to transform existing political structures: that the divided and troubled publics integrate' (LW2: 315).

In order to turn the Great Society into the Great Community, Dewey recognized that the practice of democracy as a way of life needed to be a transnational endeavour, not only between nation-state leaders but also between the various publics scattered across the globe. Reform of democracy between nation states would therefore require transnational communication and collaboration between the peoples of the world and formation of publics that would bring about changes that would bring forth global democracy. This was nothing short of a call for the global inheritance of democracy as a way of life and the rethinking and renewal of the practices and institutions of democracy in the face of the global nature of the Great Society:

The peoples of the Earth, not just their governmental officials, must find effective answers to the following questions. Is a world-government possible? How shall it be brought into being? By the unilateral and coercive action of some or one nation, or by general cooperative action? What shall be its machinery? What responsibilities shall it possess in order that a common rule of law, expressing the needs of a worldsociety, may substitute a system of peace and security for the present war system? These questions are urgent; it is imperative to face them at once, directly, and with utmost seriousness. They are not matters of abstract theory but of utmost practical concern. (LW15: 206)

The challenge of 'discovering and implementing politically areas of common interest' between publics and national units in such an interdependent world was now, Dewey decreed, the new political 'imperative' of the twentieth century (LW2: 379). Dewey was himself buoyed by developments after the Second World War. In the second preface to The Public and Its Problems, written in 1946, Dewey cited 
the formation of the United Nations and the opening of debate about the nature of the organization as evidence that there was a growing sense '...that relations between nations are taking on properties that constitute a public and hence call for some measure of political organisation'. Dewey argued that the debate within nation states as to what was 'public' and what was 'private' was being extended into the context of relations between national units. The formation of the UN signalled an acceptance by nation states of the political responsibility that each national unit had towards one another within the Great Community, as opposed to the weak moral responsibility that so easily broke down in the 1930s (LW2: 375-6). And in organizations such as UNESCO Dewey found more evidence that armed conflict was potentially being usurped as the primary method to deal with the effects of globalization. Dewey believed that UNESCO offered '... the peoples of the world a symbol of what is now desirable, and of what may become an actuality' (LW16: 400-1). Yet, as we shall examine in Chapter 3, Dewey's hope that humanity could live up to meeting the challenges of the new imperative of the twentieth century was tempered by what he saw as the eclipse of the public and democracy at home. 